$$
\text { NyS } 38
$$

NYDANSKE SPROGSTUDIER 


\section{NyS 38}

NYDANSKE SPROGSTUDIER

(C) artiklernes forfattere, 2010

Redaktion:

Tanya Karoli Christensen, Torben Juel Jensen, Niels Møller Nielsen, Nicolai Pharao,

Marianne Rathje, Jann Scheuer

Oplysninger om abonnement og indsendelse af bidrag findes bagest i nummeret.

Udgives i samarbejde med

Dansk Sprognævn

H.C. Andersens Boulevard 2

1553 København V

Tryk: Frederiksberg Bogtrykkeri A/S

\section{ISBN}

978-87-89410-29-6

Printed in Denmark, 2010 


\section{Indhold}

Forord

SØREN BECK NIELSEN

Konversationsanalyse af læge-patient-samtaler

Status, overblik og muligheder

JAKOB HALSKOV \& PIA JARVAD

Manuel og maskinel excerpering af neologismer

PETER JUUL NIELSEN

Samstemmighed som syntagmedanner

Om begrebet kongruens

IØRN KORZEN \& LITA LUNDQUIST

Dansk og andre indoeuropæiske sprog

Strukturelle forskelle mellem tekster på "endocentrisk" dansk og på

"eksocentriske" romanske sprog

ASTRID RAVN SKOVSE \& MIRIAN DUE STEFFENSEN

Stedet i sproget

RANDI BENEDIKTE BRODERSEN

Anmeldelse af Asgerd Gudiksen, Henrik Hovmark, Pia Quist, Jann Scheuer og

Iben Stampe Sletten (red.): Dialektforskning i 100 ar 
